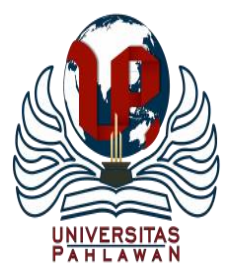

Edukatif : Jurnal Ilmu Pendidikan Volume 3 Nomor 5 Tahun 2021 Halm 2559 - 2572

EDUKATIF: JURNAL ILMU PENDIDIKAN

Research \& Learning in Education

https:/ledukatif.org/index.php/edukatif/index

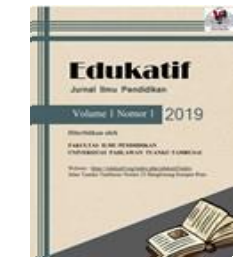

\title{
Analisis Pembiayaan Pendidikan di Madrasah Aliyah
}

\author{
Desimarnis $^{\bowtie}$ \\ Universitas Negeri Padang, Indonesia \\ E-mail : $\underline{\text { silalapa@gmail.com }}$
}

\begin{abstract}
Abstrak
Pembiayaan pendidikan di MadrasahAliyah Negeri 3 Kota Payakumbuh perlu dilakukan analisis karena perkembangan Madrasahyang terkesan lamban, jumlah peserta didik yang stagnan, salah satu faktor yang mempengaruhi perkembangan nya adalah dari biaya.. Analisis pembiayaan bertujuan untuk melihat: 1) faktor yang mempengaruhi biaya pendidikan di MadrasahAliyah Negeri 3 Kota Payakumbuh 2) Jenis pembiayaan pendidikan di MadrasahAliyah Negeri 3 Kota Payakumbuh 3) Model pembiayaan pendidikan di MadrasahAliyah Negeri 3 Kota Payakumbuh. Metode Penelitian ini menggunakan studi dokumen MadrasahAliyah Negeri 3 Kota Payakumbuh dan literatur beberapa jurnal yang disintesis untuk mengambil kesimpulan terkait penelitianyang dilakukan analisis deskriptif. Sebagai hasil penelitian bahwa faktor yang paling mendominasi lambatnya perkembangan MadrasahAliyah Negeri 3 Kota Payakumbuh adalah perubahan dalam populasi dan jumlah persentase peserta didik setiap tahun yang tidak meningkat. Semakin banyak peserta didik semakin besar biaya yang masuk. Orang tua sering mengeluhkan biaya yang harus dikeluarkan oleh orang tua peserta didik (biaya pribadi). Pembiayaan pendidikan di MadrasahAliyah Negeri 3 Kota Payakumbuh belum efektif dan belum efisien, perlu dikembangkan model pendekatan human capital.
\end{abstract}

Kata Kunci:. analisis, pembiayaan pendidikan, dan madrasah

\begin{abstract}
The financing of education in MadrasahAliyah Negeri 3 Payakumbuh needs to be analyzed because the development of Madrasas seems slow, the number of students is stagnant, one of the factors that influence its development is the cost. The analysis of financing aims to see: 1) factors that affect the cost of education in MadrasahAliyah Negeri 3 Payakumbuh 2) Types of education financing in MadrasahAliyah Negeri 3 Payakumbuh 3) Educational financing model in MadrasahAliyah Negeri 3 Payakumbuh. Methods This research uses a document study of MadrasahAliyah Negeri 3 Payakumbuh City and the literature of several journals which are synthesized to draw conclusions related to research conducted by descriptive analysis. As a result of the research that the most dominating factor for the slow development of MadrasahAliyah Negeri 3 Payakumbuh City is the change in population and the number of percentages of students each year which does not increase. The more students, the greater the entrance fee. Parents often complain about the costs that must be paid by the parents of students (personal costs). Education financing in MadrasahAliyah Negeri 3 Payakumbuh City has not been effective and not efficient, it is necessary to develop a human capital approach model.
\end{abstract}

Keywords: analysis, financing of education, and madrasah

Copyright (c) 2021 Desimarnis

$\triangle$ Corresponding author:

Email : silalapa@gmail.com

DOI : https://doi.org/10.31004/edukatif.v3i5.681

ISSN 2656-8063 (Media Cetak)

ISSN 2656-8071 (Media Online)

Edukatif : Jurnal Ilmu Pendidikan Vol 3 No 5 Tahun 2021 p-ISSN 2656-8063 e-ISSN 2656-8071 


\section{PENDAHULUAN}

Negara yang sejahtera adalah negara yang bisa memakmurkan rakyatnya. Rakyat yang makmur adalah gambaran demografi yang berkualitas. Selain pendapatan dan kesehatan, kualitas demografi ditunjukan juga oleh tingkat pendidikan masyarakatnya. Pendidikan yang berkualitas membentuk karakter dan melahirkan para intelektual karena pendidikan berkontribusi terhadap kemajuan bangsa yang dapat membangun watak cemerlang. Peningkatan kualitas pendidikan adalah pilihan sekaligus orientasi pengembangan peradaban bangsa sebagai investasi masa depan pembangunan bangsa berjangka panjang (Feiby Ismail, n.d.)

Undang-Undang (UU) Republik Indonesia (RI) Nomor 20 Tahun 2003 menyebutkan bahwa pendidikan adalah usaha sadar dan terencana untuk mewujudkan suasana belajar dan proses pembelajaran agar peserta didik secara aktif mengembangkan potensi dirinya untuk memiliki kekuatan spiritual keagamaan, pengendalian diri, kepribadian, kecerdasan, akhlak mulia, serta ketrampilan yang diperlukan dirinya, masyarakat bangsa dan negara. Pendidikan nasional memiliki visi "terwujudnya sistem pendidikan sebagai pranata sosial yang kuat dan berwibawa untuk memperdayakan semua warga negara berkembang menjadi manusia yang berkualitas sehingga mampu dan proaktif menjawab tantangan zaman yang berubah"(UU 20 tahun, 2003). Sangat jelas visi pendidikan dalam membentuk masyarakat yang siap menerima perubahan dan harus berkualitas.

Pendidikan yang berkualitas sangat ditentukan oleh pembiayaan. Pembiayaan pendidikan menjadi tanggungjawab bersama antara pemerintah pusat, pemerintah daerah dan masyarakat. Hal ini tertuang dalam UU standar pendidikan nasional Nomor 20 tahun 2003 Pasal 46 ayat 1 (UU 20 tahun, 2003). Pembiayaan pendidikan merupakan hubungan saling keterkaitan yang di dalamnya terdapat komponen-komponen yang bersifat mikro dan makro pada satuan pendidikan. Unsur nya memiliki fungsi yang berbeda, namun memiliki tujuan yang sama, yakni : a) untuk meningatkan potensi Sumber Daya Manusia (SDM); b) menyediakan sumber pembiayaan pendidikan; c) menetapkan mekanisme pengalokasian dana; d) mengefektifkan dan mengefisienkan pemakaian dana; e) Keberhasilan yang terukur dan dapat dipertanggungjawabkan; f ) meminimalis masalah dalam penggunaan pembiayaan pendidikan (Ferdi, 2013)

Keuangan dan pembiayaan merupakan salah satu sumber daya yang secara langsung menunjang efektivitas dan efisiensi pengelolaan pendidikan. Dalam hal ini, biaya dapat diartikan sebagai semua jenis pengeluaran yang berkenaan dengan penyelenggaraan pendidikan (Musthafa, 2017). Krisis dalam perekonomian di negara Indonesia seolah terus membelenggu yang berdampak pada kehidupan masyarakat kurang mampu dan terjerat kebutuhan hidup yang sulit dijangkau. Tidak bisa dipungkiri akan berimbas pada pembiayaan pendidikan. Problem pendidikan merupakan salah satu masalah bangsa yang masih belum ada ketuntasan solusinya. Saat ini biaya pendidikan dirasakan mahal terutama oleh kalangan kurang mampu. Pemberian Bantuan Operasional Madrasah (BOS) adalah salah satu solusi mahalnya biaya pendidikan.

Dana Bantuan Operasional Sekolah atau Bantuan Operasionai Pendidikan dapat digunakan untuk pengadaan barang sesuai kebutuhan sekolah termasuk untuk membiayai keperluan dalam pencegahan pandemi Covid- 19 seperti penyediaan alat kebersihan, hand sanitizer, disinfectant, dan masker bagi warga sekolah serta untuk membiayai pembelajaran daring/jarak jauh(Kemendikbud, 2020)

Pembiayaan adalah segala sesuatu yang berhubungan dengan biaya (Musthafa, 2017) Pembiayaan pendidikan merupakan unsur pokok dalam penyelenggaraan Proses Belajar Mengajar (PBM). Di dalam proses pembelajaran terdapat dua aktifitas, yaitu aktifitas mengajar (guru) dan aktifitas belajar (peserta didik). Proses pembelajaran merupakan suatu kegiatan yang berlangsung dalam suasana interaksi edukatif, yang didesain untuk suatu tujuan tertentu, maka sebagai guru dituntut untuk memiliki kemampuan didaktis, sehingga mampu memberikan motivasi di dalam proses interaksi dengan peserta didik (Asiah, 2016)

Penggunaan anggaran yang efektif dan efisien diharapkan dapat menghasilkan Sumber Daya Manusia (SDM) yang berkualitas dan didaktis. Pemerintah memegang peranan penting demi terciptanya situasi dan kondisi penyelenggaraan dan pengelolaan pendidikan yang demokratis dan berkeadilan sebagaimana 
diamanatkan dalam Pasal 4, ayat 1 Undang-Undang (UU) Republik Indonesia (RI) Nomor 20 Tahun 2003 tentang Sistem Pendidikan Nasional bahwa prinsip penyelenggaraan pendidikan, yaitu "pendidikan diselenggarakan secara demokratis dan berkeadilan serta tidak diskriminatif dengan menjunjung tinggi hak asasi manusia, nilai keagamaan, nilai kultural, dan kemajemukan bangsa"(UU 20 tahun, 2003). Kata kunci tidak diskriminatif berlaku untuk pembiayaan pendidikan, artinya bahwa pembiayaan pendidikan harusnya tidak mendiskriminatifkan warga negara yang berkeinginan untuk mengikuti pendidik an.

Ada beberapa model pembiayaan pendidikan menurut Thomas H. Jones (1985:100-131) dalam (Musthafa, 2017) berpendapat bahwa terdapat 6 (enam) model pembiayaan pendidikan, yaitu: 1) Flat grant merupakan tipe perencana bantuan pembiayaan pendidikan yang pertama dan tertua. Dalam rencana ini, setiap Madrasah memiliki sejumlah dana yang sama, yang dihitung per-siswa atau per unit pendanaan lainnya. Sebagaimana penjelasan terdahulu, akibat dari sistem bagi rata, maka Madrasah yang mengeruk uang lebih besar, sehingga atas dasar hal tersebut flat grant tidak dianggap sebagai equalizing. Flat grant bisa cocok di bawah kondisi-kondisi politik yang memiliki konsensus yang memutuskan bahwa semua distrik atau semua Madrasah mendapat bantuan yang sama terlepas dari seberapa besar kekayaan mereka atau seberapa rendah tarif pajak yang mereka berlakukan. 2) Power Equalizing dibebankan kepada daerah-daerah yang sangat kaya untuk membayarkan sebagian pajak Madrasah yang mereka pungut kembali ke kantong negara bagian. Negara bisa menggunakan uang yang dari daerah-daerah kaya untuk manambah bantuan bagi daerahdaerah yang miskin. Setiap daerah akan menerima jumlah dana berbeda tergantung pada kemampuan penghasilan daerah (APBD). Daerah miskin akan menerima 5 per mil ditambah dengan 7 per mil dana dasar daerah. Dengan demikian akan ada keseimbangan dana antar daerah-daerah yang sumber daya alamnya kaya. 3) Complete State Model adalah satu-satunya rencana pembiayaan pendidikan yang dirancang untuk menghapus semua perbedaan lokal, baik dalam pembelanjaan maupun dalam pemerolehan pajak tidak akan ada pajak property Madrasah lokal dengan berbagai taraf dan basis pajak lokal adalah unequal (tidak seimbang). Para pendukung juga mengatakan bahwa pengawasan keuangan lokal tidak efisien untuk masyarakat secara keseluruhan. Maka complete state model menempatkan lebih banyak tanggung jawab untuk akuntabilitas pendidikan secara merata di tingkat negara bagian. 4) Foundation Plan, dirancang untuk menggali empat masalah besar dalam pendidikan dan keuangan, yaitu: kesetaraan pembelanjaan, penetapanpenetapan standar pajak dan pembelanjaan Madrasah minimum, pemisahan (demarkasi) wewenang politik antara daerah-daerah Madrasah lokal dengan negara bagian, dan provisi untuk perbaikan berkesinambungan atas proses pendidikan. Para pendukungnya menganggap bahwa negara harus mematok batas-batas minimum dan pemerintah lokal harus diperbolehkan untuk melampaui batas-batas minimum hingga ke tingkatan yang memang ingin mereka lakukan. Cara kerja foundation plan adalah, pertama, negara harus menentukan biaya per siswa per tahun bagi program pendidikan yang memuaskan. Kedua, negara harus mematok tarif pajak minimum yang harus diberlakukan oleh semua distrik Madrasah. Ketiga, negara memberikan hibah (grants) kepada tiap distrik Madrasah dengan jumlah yang sama Sedangkan besarnya bantuan adalah situasional terhadap kekayaan lokal tetapi tidak pada upaya pajak. Foundation plan membagi kue dengan porsi yang sama, namun distrik-distrik miskin lebih diutamakan. 5) Guaranteed Percent Equalizing ini dimaksudkan bahwa negara membayar persentase tertentu dari total biaya pendidikan yang diinginkan oleh tiap distrik Madrasah lokal. Penyertaan persentase negara diberlakukan tinggi pada daerah- daerah Madrasah melarat, dan persentase Madrasah rendah pada daerah yang kaya. Para pendukung model ini menyatakan bahwa memaksimalkan pengawasan lokal, kesetaraan wajib pajak, dan efisiensi Madrasah lokal. Model ini juga mendukung kesetaraan pembayar pajak. Model ini memastikan atau menjamin tiap distrik Madrasah lokal dengan sejumlah dana tertentu persiswa untuk tiap per mil pajak yang dipungut secara lokal. 6) Complete Local Support, semua sumber dana dari pemerintah negara bagian atau dana dari provinsi diharapkan seluruh biaya pendidikan menjadi tanggung jawab pemerintah lokal atau daerah. Sistem ini akan memberikan dampak pada sistem pendidikan yang ada didaerah. Model pembiayaan tersebut memberikan gambaran bahwa terdapat kekurangan dan keunggulannya masing-masing. Di Indonesia pembiayaan pendidikan menjadi 
tanggung jawab bersama pemerintah pusat, pemerintah daerah, orang tua siswa, dan masyarakat. Indonesia adalah negara yang cukup konsisten dalam persoalan pendidikan dengan cara melakukan pengaturan sedemikian rupa atas pembiayaan pendidikan(Zulfa, n.d.)

Berdasarkan uraian latar belakang kajian tersebut, dapat dirumuskan permasalahan sebagai berikut: 1) faktor-faktor apa yang mempengaruhi biaya pendidikan di MadrasahAliyah Negeri 3 Kota Payakumbuh? 2) apa saja jenis biaya pendidikan MadrasahAliyah Negeri 3 Kota Payakumbuh? dan 3) model biaya pendidikan seperti apa yang dipergunakan sebagai acuan untuk operasionalisasi biaya pendidikan secara efektif dan efisien MadrasahAliyah Negeri 3 Kota Payakumbuh?. Mengacu pada permasalahan, maka tujuan kajian ini dimaksudkan untuk: 1) mengetahui faktor-faktor yang mempengaruhi biaya pendidikan MadrasahAliyah Negeri 3 Kota Payakumbuh; 2) mengidentifikasi jenis biaya pendidikan MadrasahAliyah Negeri 3 Kota Payakumbuh; dan 3) mengidentifikasi model pembiayaan pendidikan yang efektif dan efisien MadrasahAliyah Negeri 3 Kota Payakumbuh?

\section{METODE PENELITIAN}

Penelitian ini menggunakan pendekatan kualitatif dengan jenis penelitian deskriptif. Analisis data penelitian ini menggunakan analisis deskriptif. Prosesnya dilakukan semenjak pengumpulan data, sehingga saat dilapangan, peneliti sudah mulai melakukan proses analisis data hingga penelitian berakhir. Artinya, halhal yang terkait dengan teori dan konsep dasar pembiayaan (cost) di MadrasahAliyah Negeri 3 Kota Payakumbuh dianalisis secara mendalam.

Pengumpulan data melalui bendahara sekolah, bendahara komite serta badan sosial yang memberikan zakat kepada pesert didik, Para orang tua asuh dan orang tua angkat serta para guru yang menyanggupi menjadi donator tetap untuk peserta didik. Data dihimpun kemudian dilakukan analisisnya.

\section{HASIL DAN PEMBAHASAN PENELITIAN}

\section{Faktor Yang Mempengaruhi Pembiayaan Pendidikan di MadrasahAliyah Negeri 3 Kota Payakumbuh}

Menurut Levin (1987) pembiayaan Madrasah adalah proses dimana pendapatan dan sumberdaya tersedia digunakan untuk memformulasikan dan mengoperasionalkan Madrasah di berbagai wilayah geografis dan tingkat pendidikan yang berbeda-beda (Fattah, 2008). Konsep biaya mengacu pada konsep produksi, tetapi apabila pada konsep produksi kita membicarakan penggunaan input secara fisik dalam menghasilkan output produksi, maka dalam konsep biaya kita menghitung penggunaan input itu dalam nilai ekonomi yang disebut biaya (Ferdi, 2013). Jadi biaya merupakan nilai uang pendapatan dari suatu pengorbanan atas sumber ekonomi baik berupa jasa atau barang guna memperoleh pendapatan atau penghasilan masa sekarang atau masa mendatang.

Unsur-Unsur Biaya Produksi Supriono (2011) dalam (Helmina, 2013) menyatakan,unsur-unsur biaya produksi yaitu : a). Biaya bahan baku adalah bahan yang akan diolah menjadi produk selesai dan pemakaiannya dapat diidentifikasi atau diikuti jejaknya atau merupakan bagian integral pada produk tertentu. b). Biaya tenaga kerja adalah semua balas jasa (teken prestasi)yang diberikan oleh perusahaan kepada semua karyawan. c). Biaya overhead pabrik adalah biaya produksi selain bahan baku dan tenaga kerja langsung., yang elemennya dapat digolongkan ke dalam : biaya bahan penolong, biaya tenaga kerja tidak langsung, penyusutan dan amorrtisasi aktiva tetap pabrik, reparasi dan pemeliharaanaktiva tetap, biaya listrik dan air pabrik, biaya asuransi pabrik, biaya overhead lain-lain. d).Biaya Pemasaran, yaitu biaya dalam rangka penjualan produk selesai sampai dengan pengumpulan piutang menjaddi kas. Biaya ini meliputi : fungsi penjualan, fungsi penggudangan produk selesai, fungsi pengepakan dan pengiriman, fungsi adpertensi, fungsi pembuatan faktur atau administrasi penjualan. e). Biaya administrasi dan umum, yaitu semua biaya yang berhubungan dengan fungsi administrasi dan umum. Biaya ini terjadi dalam rangka penentuan kebijaksanaan, pengarahan, dan pengawasan kegiatan perusahaan secara keseluruhan. f) Biaya keuangan adalah semua biaya yang terjadi dalam melaksanakan fungsi keuangan. 
Dalam rangka menghasilkan kualitas Sumber Daya Manusia Indonesia yang sesuai dengan kebijakan arah pendidikan nasional, perlu dikembangkan suatu kurikulum pendidikan yang tepat. Pengembangan kurikulum harus memperhatikan satandar pendudkung pendidikan yang meliputi: (1) standar saranaprasarana, (2) standar tenaga pendidikan \& kependidikan, (3) standar pembiayaan, dan (4) standar pengelolaan (Supardi, 2015)

Pembiayaan Pendidikan adalah bagian faktor penting guna meningkatkan kualitas Sumber Daya Manusia (SDM). Dalam UUD 1945 Pasal 31 hasil amandemen mempertegas kebijakan arah pendidikan bangsa Indonesia yaitu, "Pemerintah mengusahakan dan menyelenggarakan satu sistem pendidikan nasional, yang meningkatkan keimanan dan ketakwaan serta akhlak mulia dalam rangka mencerdaskan kehidupan bangsa"(Helmina, 2013). Hal ini membuktikan adanya langkah pemerataan pendidikan bagi seluruh warga negara Indonesia. Kenyataannya, tidak semua orang dapat memperoleh pendidikan yang layak. Hal ini dikarenakan berbagai faktor, termasuk mahalnya biaya pendidikan yang harus dikeluarkan. Kondisi inilah kemudian mendorong dimasukannya klausal tentang pendidikan dalam amandemen UUD 1945.

Konstitusi (UUSPN Nomor 20/2003) mengamanatkan kewajiban Pemerintah untuk mengalokasikan biaya pendidikan 20\% dari APBN maupun APBD agar masyarakat dapat memperoleh pelayanan pendidikan sesuai dengan misi Kemdiknas 5 (lima) K, yaitu: ketersediaan layanan pendidikan; keterjangkauan layanan pendidikan; kualitas dan relevansi layanan pendidikan; kesetaraan layanan pendidikan; dan kepastian memperoleh layanan pendidikan. Dalam upaya pembangunan bidang pendidikan ini, undang-undang dasar hasil amandemen telah mengamanatkan bahwa minimal 20\% APBN/APBD diperuntukkan untuk bidang pendidikan (Helmina, 2013) Jaminan ketentuan bahwa ada pengalokasian dana untuk penyelenggaraan pendidikan. Namun, dalam pelaksanaannya Pemerintah belum memiliki kapasitas finansial yang mencukupi, sehingga alokasi dana tersebut dicicil/dilakukan secara bertahap dan berkesinambungan dengan komitmen peningkatan alokasi setiap tahunnya.

Peningkatan kualitas pendidikan diharapkan dapat menghasilkan manfaat berupa peningkatan kualitas Sumber Daya Manusia (SDM). Dalam rangka menghasilkan kualitas Sumber Daya Manusia (SDM) Indonesia yang sesuai dengan kebijakan arah pendidikan nasional, perlu dikembangkan suatu kurikulum pendidikan yang tepat. Dalam pengembangan kurikulum pendidikan harus termuat empat standar yang saling terkait, yaitu: (1) standar kompetensi (tujuan pendidikan), (2) standar isi (materi/tema pembelajaran), (3) standar proses, dan (4) standar evaluasi (penilaian) (Helmina, 2013).

Dalam pengembangan kurikulum harus memperhatikan agar semua ranah pendidikan atau potensi peserta didik dapat dibangun dan dikembangkan. Selain itu, pengembangan kurikulum harus memperhatikan standar pendukung pendidikan yang meliputi: (1) standar sarana-prasarana, (2) standar tenaga pendidikan \& kependidikan, (3) standar pembiayaan, dan (4) standar pengelolaan (Helmina, 2013). Di sisi lain, prioritas alokasi pembiayaan pendidikan seharusnya diorientasikan untuk mengatasi permasalahan dalam hal aksesibilitas dan daya tampung. Oleh karena itu, dalam mengukur efektivitas pembiayaan pendidikan terdapat sejumlah prasyarat yang perlu dipenuhi agar alokasi anggaran yang tersedia dapat terarah penggunaannya.

\section{Model Pembiayaan Pendidikan di Madarasah Aliyah Negeri 3 Kota Payakumbuh}

Human Capital yang berupa kemampuan dan kecakapan yang diperoleh melalui pendidikan, belajar sendiri, belajar sambil bekerja memerlukan biaya yang dikeluarkan oleh yang bersangkutan. Perolehan keterampilan dan kemampuan akan menghasilkan tingkat balik rate of return yang sangat tinggi terhadap penghasilan seseorang. Berdasarkan pendekatan Human Capital terdapat hubungan linier antara investasi pendidikan dengan Higher Productivity dan Higher Earning. Manusia sebagai modal dasar yang diinvestasikan akan menghasilkan manusia terdidik yang produktif dan meningkatnya penghasilan sebagai akibat dari kualitas kerja yang ditampilkan oleh manusia terdidik. Dengan demikian, manusia yang memperoleh penghasilan lebih besar akan membayar pajak dalam jumlah yang besar, sehingga dengan sendirinya dapat meningkatkan pendapatan negara. 
Peningkatan keterampilan yang dapat menghasilkan tenaga kerja yang produktivitasnya tinggi dapat dilakukan melalui pendidikan yang dalam pembiayaannya menggunakan efisiensi internal dan eksternal. Dalam upaya mengem- bangkan suatu sistem pendidikan nasional yang berporos pada pemerataan, relevansi, mutu, efisiensi, dan efektivitas dikaitkan dengan tujuan dan cita-cita pendidikan, namun dalam kenya- taannya perlu direnungkan, dikaji, dan dibahas, baik dari segi pemikiran teoritis maupun pengamatan empiric

Untuk dapat tercapai tujuan pendidikan yang optimal, salah satu hal paling penting, yaitu mengelola biaya dengan baik sesuai dengan kebutuhan dana yang diperlukan. Administrasi pembiayaan minimal mencakup perencanaan, pelaksanaan, dan pengawasan. Penyaluran anggaran perlu dilakukan secara strategis dan integratif antara pemangku kepentingan (stakeholder) untuk mewujudkan kondisi ini, perlu dibangun rasa saling percaya, baik internal Pemerintah maupun antara Pemerintah dengan masyarakat dan masyarakat dengan masyarakat itu sendiri dapat ditumbuhkan. Keterbukaan, partisipasi, dan akuntabilitas dalam penyelenggaraan pendidikan mulai dari perencanaan, pelaksanaan, dan pengawasan menjadi kata- kata kunci untuk mewujudkan efekt ivitas pembiayaan pendidikan.

Pembiayaan pendidikan MadrasahAliyah Negeri 3 Kota Payakumbuh, terdiri atas biaya investasi, biaya operasi, dan biaya personal. Biaya investasi satuan pendidikan sebagaimana dimaksud di atas meliputi biaya penyediaan sarana dan prasarana, pengembangan sumber daya manusia, dan modal kerja tetap. Lebih lanjut, biaya personal meliputi biaya pendidikan yang harus dikeluarkan oleh peserta didik untuk bisa mengikuti proses pembelajaran secara teratur dan berkelanjutan. Biaya operasi MadrasahAliyah Negeri 3 Kota Payakumbuh sebagaimana dimaksud meliputi: a) gaji pendidik dan tenaga kependidikan serta segala tunjangan yang melekat pada gaji; b) bahan atau peralatan pendidikan habis pakai; dan c) biaya operasi pendidikan tak langsung berupa daya, air, jasa telekomunikasi, pemeliharaan sarana dan prasarana, uang lembur, transportasi, konsumsi, pajak, asuransi, dan lain sebagainya.

Faktor yang mempengaruhi pembiayaan di MadrasahAliyah Negeri 3 Kota Payakumbuh antara lain karena kenaikan harga, perubahan gaji guru, perubahan dalam jumlah populasi dan kenaikan porsentase peserta didik, meningkatnya standar pendidikan dan meningkatnya usia anak yang meninggalkan Madrasah. Hal tersebut sesuai dengan yang disampaikan oleh Iskandar, 2013 dalam (Sopiali, 2018) faktor-faktor yang mempengaruhi pembiayaan pendidikan Madrasah dipengaruhi oleh: 1) kenaikan harga (rising prices); 2) perubahan relatif dalam gaji guru (teacher's sallaries); 3) perubahan dalam populasi dan kenaikannya prosentasi anak di Madrasah negeri; 4) meningkatnya standar pendidikan (educational standards); 5) meningkatnya usia anak yang meninggalkan Madrasah; dan 6) meningkatnya tuntutan terhadap pendidikan lebih tinggi (higher education).

Dari tahun ketahun biaya pendidikan di Madrasah berfluktuatif namun cenderung meningkat (Sunarsi, 2013). MadrasahAliyah Negeri 3 Kota Payakumbuh tidak jauh berbeda dengan pernyataan Sunarsi tersebut. Setiap tahun ajaran biaya pendidikan menjadi bagian dari strategi ketika menjaring minat siswa mendaftar untuk melanjutkan pendidikan di MadrasahAliyah Negeri 3 Kota Payakumbuh. Perekrutan peserta didik melalui proses seleksi. Jumlah peserta didik yang banyak akan berbanding lurus dengan pendapatan Madrasah, sehingga upaya maksimal dalam promosi dengan tujuan untuk meningkatnya kuantitas serta kualitas peserta didik dapat berbuah hasil. Dengan biaya yang stabil sesuai perbandingan pengguna biaya mampu dipertahankan tentu dapat meningkatkan kelangsungan kegiatan Madrasahdisebabkan biaya yang cukup. Untuk mengetahui seberapa besar perubahan kenaikan biaya pendidikan setiap tahunnya, berikut ini perkembangan biaya pendidikan pada di MadrasahAliyah Negeri 3 Kota Payakumbuh selama kurun waktu tiga tahun yaitu tahun 2020-2018 dalam tabel dan analisanya sebagai berikut:

\section{Tabel 1}

Rincian Biaya di MadrasahAliyah Negeri 3 Kota Payakumbuh periode 2018-2020

\begin{tabular}{ccccc}
\hline No & Rincian Biaya (Rp) & 2018 & 2019 & 2020 \\
\hline 1 & Matsama & 10.000 & 15.000 & 25.000 \\
\hline 2 & Infak Pendidikan & 90.000 & 90.000 & 100.000 \\
\hline
\end{tabular}




\begin{tabular}{clccc}
\hline 3 & Infak Pembangunan & 200.000 & 450.000 & 750.000 \\
\hline 4 & Pakaian & 750.000 & 800.000 & 950.000 \\
\hline 5 & Osim & 5000 & 10.000 & 15.000 \\
\hline 6 & Perlengkapan & 50.000 & 150.000 & 200.000 \\
\hline & Jumlah & 1.550 .000 & 1.515 .000 & 2.040 .000 \\
\hline
\end{tabular}

Sumber : Data Tata Usaha Bendaharaa Komite Juni 2021

Dari tabel di atas, tidak terjadi peningkatan yang signifikan pembiayaan pendidikan diMadrasahAliyah Negeri 3 Kota Payakumbuh. Untuk tahun 2018 dan 2019 bisa dikatakan hampir sama. Namun untuk tahun 2020 terjadi kenaikan sebanyak 34\% yakni dari Rp. 1.515 .000 menjadi Rp. 2.040 .000 , kenaikan tersebut menyesuaikan harga pakaian serta keperluan perlengkapan sesuai kebutuhan. Pembangunan lokal baru juga sudah disepakati bersama komite dan untuk pembangunan lokal baru membutuhkan biaya yang lumayan besar tidak sebanding dengan jumlah peserta didik yang stagnan tidak bertambah. Berikut disampaikan jumlah peserta didik selama 3 tahun terakhir.

Tabel 2

Rincian Jumlah peserta didik MadrasahAliyah Negeri 3 Kota Payakumbuh periode 2018-2020

\begin{tabular}{ccccc}
\hline No & Rincian Biaya (Rp) & 2018 & 2019 & 2020 \\
\hline 1 & M I P A (Kelas X sd XII) & 45 & 43 & 46 \\
\hline 2 & I P S (Kelas X sd XII) & 76 & 75 & 66 \\
\hline 3 & I P K (Kelas X sd XII) & 55 & 54 & 66 \\
\hline & Jumlah & 176 & 172 & 178 \\
\hline
\end{tabular}

Sumber : Data Tata Usaha MAN 3 Kota Payakumbuh

Dari tabel di atas, jumlah peserta didik dari tahun ke tahun tidak ada peningkatan yang signifikan. Dengan jumlah kelas 9 ruang jumlah seharusnya peserta didik bisa mencapai 288 orang dengan 32 orang per rombel. namun peserta didik MadrasahAliyah Negeri 3 Kota Payakumbuh tidak pernah mencapai 200 orang. Sebagai Madrasahnegeri, permasalahan ini sudah menjadi permasalahan pokok setiap penerimaan peserta didik baru. Para tenaga pendidik dan tenaga kependidikan sudah terbiasa dengan jumlah peserta didik yang hanya di bawah 200 orang tersebut. Dan jika dikaitkan dengan biaya pendidikan tentu pembiayaan tidak bisa maksimal karena pemasukan sedikit dengan kegiatan yang juga serba terbatas. Maka perkembangan kearah kualitas akan terkendala.

Dilihat dari faktor gaji guru MadrasahAliyah Negeri 3 Kota Payakumbuh juga merasa kesulitan biaya, karena jumlah guru sukarela lebih besar dari jumlah guru yang berstatus Aparatul Sipil Negara (ASN). Guru sukarela mendapat honornya dari infak pendidikan peserta didik. Sehingga dengan honor yang kecil para guru honor tentu juga akan memiliki kesejahateraan rendah, dan honor yang rendah akan berpengaruh kepada kualitas kerja yang rendah pula.

Peserta didik MadrasahAliyah Negeri 3 Kota Payakumbuh, 80\% berada pada kelas ekonomi rendah. Rata-rata mata pencaharian orang tua adalah petani dan buruh harian lepas yang tidak memiliki penghasilan tetap, melainkan bekerja dengan orang lain dan menerima upah harian. Dengan maksimal gaji harian hanya berada pada Rp. 100.000 / hari. Peserta didik sebanyak 20\% berada pada keluarga yang broken home / keluarga kacau sehingga peserta didik mengalami trauma jiwa yang membunuh motivasi belajarnya. 5\% dari total jumlah peserta didik putus Madrasah karena tidak mampu membiayai pendidikannya sehingga mereka harus bekerja demi menyambung hidup.

Jadi faktor kenaikan harga, perubahan gaji guru, perubahan jumlah populasi yang ada di MadrasahAliyah Negeri 3 Kota Payakumbuh bisa mendeskripsikan analisis pembiayaan yang tidak mencukupi. Pembiayaan yang tidak cukup akan menghambat Madrasahuntuk berkembang. MadrasahALiyah Negeri 3 Kota Payakumbuh mengalami kelambatan perkembangan. Minim prestasi dan minim jumlah populasinya. Hal ini menjadi tantangan dan pekerjaan rumah yang besar bagi kepala Madrasahberikutnya dan sang pembuat keputusan. 


\section{Jenis Biaya Pendidikan}

Beberapa jenis dan golongan biaya pendidikan di MadrasahAliyah Negeri 3 Kota Payakumbuh. Pertama, biaya langsung (direct cost) diartikan sebagai pengeluaran uang yang secara langsung membiayai penyelenggaraan pendidikan, pengajaran, di MadrasahAliyah Negeri 3 Kota Payakumbuh. Biaya langsung juga diartikan sebagai biaya yang secara langsung menyentuh aspek dan proses pendidikan. Sebagai contoh biaya untuk gaji guru dan pengadaan fasilitas belajar-mengajar di MadrasahAliyah Negeri 3 Kota Payakumbuh. Biaya-biaya yang dikeluarkan untuk keperluan pelaksanaan pengajaran dan kegiatan belajar peserta didik berupa pembelian alat-alat pelajaran, sarana belajar, biaya transportasi, dan gaji guru, baik yang dikeluarkan oleh Pemerintah orang tua, maupun peserta didik sendiri (Fattah, 2008) Biaya langsung (direct cost), yaitu: 1) Biaya rutin (recurrent cost), merupakan biaya yang digunakan untuk membiayai kegiatan operasional pendidikan selama satu tahun anggaran. Biaya ini digunakan untuk menunjang pelaksanan program pengajaran, pembayaran gaji guru, dan personil Madrasah, administrasi kantor, pemeliharaan dan perawatan sarana dan prasarana. Biaya langsung MadrasahAliyah Negeri 3 Kota Payakumbuh pada tahun 2021 berjumlah Rp. 3.810.490.000 yang dipergunakan untuk membiayai penyekenggaran pendidikan.

Pembiayaan selanjutnya adalah biaya rutin yang dihitung berdasarkan "per student enrolled". Biaya rutin dipengaruhi oleh 3 (tiga) faktor utama, yaitu: 1) rata-rata gaji guru per tahun; 2) ratio guru, murid dan proporsi gaji guru terhadap keseluruhan biaya rutin; dan 3) biaya pembangunan (capital cost), merupakan biaya yang digunakan untuk pembelian tanah, pembangunan ruang kelas, perpustakaan, lapangan olah raga, konstruksi bangunan, pengadaan perlengkapan mobilair, biaya penggantian dan perbaikan. Biaya pembangunan dihitung atas dasar "per student place". Dalam menghitung biaya pembangunan ada beberapa faktor yang harus dipertimbangkan, yaitu pertama: tempat yang menyenangkan untuk murid belajar, biaya lokasi atau tapak (site), dan biaya perabot dan peralatan. Kedua: biaya tidak langsung (indirect cost) dapat dimaknai sebagai biaya yang umumnya meliputi hilangnya pendapatan peserta didik karena sedang mengikuti pendidikan (earning foregone by students), bebasnya beban pajak karena sifat Madrasah yang tidak mencari laba (cost of tax exemption), bebasnya sewa perangkat Madrasah yang tidak dipakai secara langsung dalam proses pendidikan serta penyusutan sebagai cermin pemakaian perangkat Madrasah yang sudah lama dipergunakan (implicit rent and depreciation) (Fattah, 2008)

Kita mengenal jenis-jenis biaya yang merupakan bagian dari biaya tidak langsung (indirect cost), yaitu: 1) biaya pribadi (private cost), adalah biaya yang dikeluarkan keluarga untuk membiayai Madrasah anaknya dan termasuk di dalamnya forgone opportunities. Dalam kaitan ini, Jones (1985) mengatakan "In the context of education these include tuitions, fees and other expenses paid for by individuals". Dengan kata lain, biaya pribadi adalah biaya Madrasahyang dibayar oleh keluarga atau individu; 2) biaya masyarakat (social cost), adalah biaya yang dikeluarkan oleh masyarakat untuk membiayai Madrasah(di dalamnya termasuk biaya pribadi). Dalam kaitan ini, Thomas, H. Jones (1985) mengatakan "Sometimes called public cost, the include cost of educations financed through taxation. Most public school expenses are examples of sosial costs". Dengan kata lain, biaya masyarakat adalah biaya Madrasahyang dibayar oleh masyarakat.

Ketiga, monetary cost adalah semua bentuk pengeluaran dalam bentuk uang, baik langsung maupun tidak langsung yang dikeluarkan untuk kegiatan pendidikan. Keempat. non monetary Cost adalah semua bentuk pengeluaran yang tidak dalam bentuk uang, meskipun dapat dinilai ke dalam bentuk uang, baik langsung maupun tidak langsung yang dikeluarkan untuk kegiatan pendidikan, misalnya materi, waktu, tenaga, dan lain-lain.

Dalam Peraturan Pemerintah Nomor 19 Tahun 2007 tentang Standar Nasional Pendidikan (SNP) Pasal 62 disebutkan bahwa pembiayaan pendidikan terdiri atas biaya investasi, biaya operasi, dan biaya personal (Presiden Republik Indonesia, 2008). Biaya investasi satuan pendidikan meliputi biaya penyediaan sarana dan prasarana, pengembangan sumber daya manusia, dan modal kerja tetap. Biaya operasi satuan pendidikan meliputi: gaji pendidik dan tenaga kependidikan serta segala tunjangan yang melekat pada gaji; bahan atau peralatan habis pakai; dan biaya operasi pendidikan tak langsung berupa daya, air, jasa telekomunikasi, uang 
lembur, transportasi, konsumsi, pajak, asuransi, dan lain sebagainya. Adapun biaya personal meliputi biaya pendidikan yang harus dikeluarkan oleh peserta didik untuk bisa mengukuti proses pembelajaran secara teratur dan berkelanjutan

Sementara itu, Peraturan Pemerintah Nomor 48 Tahun 2008 tentang Pendanaan Pendidikan (Pasal 7 sampai dengan Pasal 30), pendanaan pendidikan menjadi tanggung jawab Pemerintah dan pemerintah daerah yang terdiri atas lima jenis, yaitu: 1) biaya investasi satuan pendidikan, meliputi: a) biaya investasi lahan pendidikan dan b) biaya investasi selain lahan pendidikan; 2) biaya investasi penyelenggaraan dan/atau pengelolaan pendidikan, meliputi: a) biaya investasi lahan dan b) biaya investasi selain lahan; 3) biaya operasi satuan pendidikan, meliputi: a) biaya personalia dan b) biaya nonpersonalia; 4) biaya operasi penyelenggaraan dan/atau pengelolaan pendidikan,yang meliputi: a) biaya personalia dan b) biaya nonpersonalia; serta 5) bantuan biaya pendidikan dan beasiswa (Peraturan Pemerntah, 2008)

Dalam perkembangannya, kebutuhan pen- danaan pendidikan merupakan salah satu permasalahan yang cukup pelik untuk dikelola secara efektif dan efisien. Permasalahan pendanaan pendidikan erat kaitannya dengan keperluan operasionalisasi penyelenggaraan pendidikan. Biaya tersebut, antara lain: 1) biaya operasional pendidik dan tenaga kependidikan (gaji dan honor/insentif/tunjangan); 2) proses pembelajaran dan penilaian; 3) pengadaan, perawatan, dan perbaikan/perawatan sarana-prasarana pendidikan; dan 4) manajemen

Fungsi pembiayaan tidak dapat terpisahkan dengan Standar Nasional Pendidikan (SNP). Oleh karena itu, pembiayaan menjadi masalah sentral dalam pengelolaan penyelenggaraan pendidikan yang harus disikapi dan dicarikan berbagai alternatif solusinya. Ketidakmampuan lembaga penyelenggara pendidikan untuk menyediakan pendanaan pendidikan akan menghambat proses operasionalisasi penyelenggaraan pendidikan itu sendiri. Namun demikian, bukan jaminan manakala tersedia biaya pendidikan yang memadai akan menjamin penyelenggaraan pendidikan berhasil lebih baik. Dalam memahami permasalahan pembiayaan pendidikan di Indonesia, perlu memahami permasalahan apa saja yang timbul serta alternatif penyelesaiannya (Presiden Republik Indonesia, 2008)

Berdasarkan uraian klasifikasi biaya pendidikan, maka jelaslah bahwa biaya pendidikan memiliki pengertian yang luas. Hampir segala pengeluaran yang bersangkutan dengan penyelenggaraan pendidikan dianggap sebagai biaya. Oleh karena itu, diperlukan kebijaksanaan dalam melakukan klasifikasi biaya pendidikan untuk mencapai tujuan yang dituju semua pihak yaitu kesuksesan pelaksanaan pendidikan. tersedia biaya pendidikan yang memadai akan menjamin penyelenggaraan pendidikan berhasil lebih baik. Dalam memahami permasalahan pembiayaan pendidikan di Indonesia, perlu memahami permasalahan apa saja yang timbul serta alternatif penyelesaiannya.

Menyikapi tuntutan masyarakat dewasa ini terhadap mutu pendidikan yang tinggi, maka perlu mengadopsi sistem pembiayaan subsidi silang di mana dalam sistem tersebut diprioritaskan untuk siswa yang tidak memiliki akses kepada pendidikan karena secara ekonomi kurang mampu. Ini tercermin dalam Pasal 52 huruf f, Peraturan Pemerintah Republik Indonesia Nomor 48 Tahun 2008 tentang Pendanaan Pendidikan di mana salah satu ketentuannya menetapkan bahwa dana pendidikan satuan pendidikan yang diselenggarakan oleh Pemerintah Pusat maupun Pemerintah daerah menerapkan sistem subsidi silang yang diatur tersendiri oleh satuan pendidikan (Peraturan Pemerntah, 2008)

Berdasarkan hasil studi pembiayaan pendidikan di MadrasahDasar Negeri yang dilakukan Fattah (1998) penelitian terdahulu terungkap bahwa faktor-faktor internal Madrasahmemberikan kontribusi signifikan terhadap mutu pendidikan, yaitu: 1) kesejahteraan guru; 2) kemampuan guru; 3) sarana kelas; dan 4) bukubuku pelajaran. Keempat komponen tersebut dalam penyusuna RAPBM memerlukan skala prioritas dalam mendapatkan alokasi biaya

Faktor eksternal pendidikan, seperti keadaan ekonomi orang tua murid, aspirasi keluarga sangat berpengaruh terhadap pencapaian prestasi-prestasi siswa. Hal itu dibuktikan dari hasil studi, yang dilakukan oleh Fattah (1999) bahwa mutu pendidikan di daerah perkotaan lebih tinggi daripada di daerah pedesaan yang keadaan sosial ekonominya kurang. Madrasah-Madrasahyang memiliki orang tua murid dengan lingkungan 
keluarga mampu mempunyai fasi litas yang bermutu, guru lebih berkemampuan menciptakan pengelolaan belajar baik, yang memungkinkan siswa belajar lebih baik dan pada akhirnya prestasi muridnya jauh lebih baik.

Menurut Fattah (2006) melihat perkembangannya, anggaran mempunyai manfaat yang dapat digolongkan dalam tiga jenis, yaitu: 1) sebagai alat penaksir; 2) sebagai alat otorisasi pengeluaran dana, dan; 3) sebagai alat efisiensi. Anggaran sebagai alat efisiensi merupakan fungsi yang paling esensial dalam pengendalian. Dari segi pengendalian jumlah anggaran yang didasarkan atas angka-angka yang standar dibandingkan dengan realisasi biaya yang melebihi atau kurang, dapat dianalisis ada tidaknya pemborosan atau penghematan. Peranan anggaran dalam pengelolaan pembelajaran yang berkaitan dengan layanan belajar dan manajemen Madrasah serta manajemen Madrasah secara keseluruhan tentu sangatlah penting untuk mencapai tujuan. Anggaran pendidikan merupakan pola organisasi yang dirinci menjadi elemen-elemen dari rencana terpadu ke dalam komponen bagian atau departemen yang memudahkan biaya estimasi. Efisiensi pendidikan menggambarkan hubungan antara input dan output atau antara masukan dan keluaran. Suatu sistem yang efisien ditunjukkan oleh keluaran yang lebih untuk sumber masukan, efisiensi pendidikan mempunyai kaitan antara penda- yagunaan sumber-sumber pendidikan yang terbatas sehingga mencapai optimalisasi yang tinggi

Penyusunan anggaran merupakan salah satu langkah positif untuk merealisasikan rencana yang telah ditetapkan. Dalam penyusunan anggaran dapat menggunakan sistem kombinasi yang merupakan sistem yang lebih baik, karena sistem penganggaran ini telah melalui proses pemilihan kebutuhan yang menjadi prioritas dengan anggaran yang telah ditentukan berdasarkan perkiraan. Metoda penetapan biaya dengan memperkirakan pengeluaran berdasarkan laporan lembaga-lembaga pendidikan, menggunakan Perencanaan Penyusunan Program dan Pengajaran.

Dalam penggunaan anggaran harus memenuhi kriteria sebagai berikut: 1) harus ada laporan dari biaya; 2) laporan harus dibuat secara uniform, yaitu dengan standar fungsional yang sama; dan 3) laporan harus memperlihatkan keseluruhan biaya operasi lembaga itu. Biaya yang harus dikeluarkan dalam penyelenggaraan pendidikan meliputi biaya langsung (direct cost) dan biaya tidak langsung (indirect cost) perhitungan biaya pendidikan ditentukan oleh kegiatan dan biaya satuan, meliputi gaji guru, sarana prasarana pembelajaran dan dukungan pembiayaan mencakup pengadaan dan pemeliharaan

Pembiayaan pendidikan yang efektif dan efisien merupakan tanggung jawab bersama, baik Pemerintah maupun masyarakat. Perlu dibangun rasa saling percaya, baik internal Pemerintah maupun antara Pemerintah dengan masyarakat dan masyarakat dengan masyarakat itu sendiri dapat ditumbuhkan. Keterbukaan, partisipasi, akuntabilitas dalam penyelenggaraan pendidikan mulai dari perencanaan, pelaksanaan dan pengawasan menjadi kata kunci untuk me- wujudkan efektivitas pembiayaan pendidikan. Biaya pendidikan di Indonesia saat ini tidak murah lagi jika dilihat dari penghasilan rakyat Indonesia set iap harinya. Masalah mahalnya biaya pendidikan tidak hanya pendidikan di perguruan tinggi, melainkan juga biaya pendidikan di Madrasah dasar sampai Madrasah menengah ke atas walaupun sekarang ini Madrasah sudah mendapat bantuan operasional Madrasah (BOS).

Namun semuanya masih belum mencukupi biaya pendidikan bagi masyarakat yang kurang mampu. Pembiayaan pendidikan terdiri atas biaya investasi, biaya operasi, dan biaya personal. Biaya investasi satuan pendidikan mel iput i biaya penyediaan sarana dan prasarana, pengem- bangan sumber daya manusia, dan modal kerja tetap. Biaya personal meliputi biaya pendidikan yang harus dikeluarkan oleh peserta didik untuk bisa mengikuti proses pembelajaran. Biaya operasi satuan pendidikan meliputi gaji pendidik dan tenaga kependidikan serta segala tunjangan yang melekat pada gaji, bahan atau peralatan pendidikan habis pakai dan biaya operasi pendidikan tak langsung berupa daya, air, jasa telekomunikasi , pemel iharaan sarana dan prasarana, uang lembur, transportasi, konsumsi, pajak, asuransi, dan lain sebagainya. Komplek- sitas biaya yang timbul berdasarkan uraian di atas merupakan suatu proses yang secara bersama- sama harus ditelaah, 
diselesaikan, dan diharapkan dapat menghasilkan suatu model pembiayaan pendidikan yang terbaik sebagai upaya dalam mewujudkan cita-cita pendidikan nasional menuju masyarakat yang adil dan makmur.

\section{Analisis Biaya Pendidikan MadrasahAliyah Negeri 3 Kota payakumbuh}

Biaya pendidikan di Indonesia merupakan salah satau masalah yang dirasakan masih krusial, Meskipun masalah pembiayaan seutuhnya tidak sepenuhnya berpengaruh langsung terhadap kualitas pendidikan, namun pembiayaan berkaitan erat dengan kelancaran pembelajaran di Madrasah, termasuk pengadaan saranaprasarana dan sumber belajar. Berapa banyak Madrasahyang tidak dapat melakukan kegiatan belajar-mengajar secara optimal hanya karena masalah keuangan baik untuk menggaji guru maupun untuk pengadaan sarana dan prasarana pembelajaran. Dalam kaitan ini, meskipun tuntutan reformasi menghendaki pendidikan yang murah dan berkualitas, namun pendidikan yang berkualitas senantiasa memerlukan biaya yang tidak sedikit.

Oleh karena itu, MadrasahAliyah Negeri 3 Kota payakumbuh seharusnya mampu mengelola keuangan yang ada sehingga dapat menghindari penggunaan biaya yang tidak perlu/ tidak direncanakan dalam Rencana Anggaran Pendapatan dan Belanja Madrasah(RAPBM). Efektivitas pembiayaan merupakan salah satu alat ukur efisiensi, sehingga program kegiatan tidak hanya dihitung berdasarkan biaya tetapi juga waktu, dan lebih penting lagi menghindari dan menseleksi penggunaan dana operasional, pemeliharaan, dan biaya lain yang mengarah pada pemborosan.

Madrasahsecara mandiri dan berkewenangan penuh mengelola anggaran biaya secara efisien. Sebagai contoh efektivitas dan efisiensi dalam penyelenggaraan pendidikan yang dilakukan Pemerintah Kabupaten Jembrana-Bali. Kabupaten tersebut sejak tahun 2001 mampu memberikan pendidikan gratis 12 tahun bagi warga asli daerah tersebut. Pemerataan pendidikan, manajemen pendidikan yang efektif, dan peningkatan partisipasi masyarakat merupakan pijakan dalam melancarkan program pendidikan di Kabupaten Jembrana

Contoh lain, implementasi konsep manajemen berbasis Madrasah(MBM) pada hakikatnya menampilkan konsep pengelolaan anggaran pendidikan dengan tujuan untuk menjawab persoalan bagaimana mendayagunakan sumber- sumber pembiayaan secara efektif dan efisien?serta bagaimana mengembangkan sumber- sumber baru pembiayaan bagi pembangunan pendidikan? agar tujuan pendidikan dapat tercapai secara optimal. Dalam kondisi dana yang sangat terbatas dan Madrasah dihadapkan pada kebutuhan yang beragam, maka Madrasah harus mampu membuat keputusan dengan tetap berpedoman pada peningkatan mutu. Manakala Madrasah memiliki rencana untuk mengadakan perbaikan fasilitas. seperti pagar Madrasah atau merencanakan pengadaan alat laboratorium, maka Madrasah perlu mempertimbangkan prioritas mana yang diasumsikan memiliki pengaruh yang dominan terhadap peningkatan mutu proses belajar- mengajar. Apabila melalui berbagai pertimbangan dan atas dasar musyawarah dan mufakat dengan para pemangku kepentingan, pengadaan alat peraga laboratorium lebih memiliki dampak yang kuat, maka keputusan yang paling efisien mengadakan alat peraga laboratorium.

Efisiensi pendanaan pendidikan ditentukan oleh ketepatan dalam mendayagunakan anggaran pendidikan dengan memberikan prioritas pada faktor-faktor input pendidikan yang dapat memacu prestasi belajar peserta didik. Rencana Anggaran Pendapatan dan Belanja Madrasah(RAPBM) merupakan suatu rancangan pembiayaan pendidikan di Madrasahdalam rangka mengatur dan mengalokasikan dana pendidikan yang sumbernya sudah terkalkulasi jumlah dan besarannya, baik merupakan dana rutin bantuan dari Pemerintah berupa dana bantuan operasional atau dana lain yang berasal dari sumbangan masyarakat atau orang tua peserta didik.

Dalam merancang dan menyususun RAPBM ada beberapa hal yang harus diperhatikan, di antaranya masalah efektivitas pembiayaan sebagai salah satu alat ukur efisiensi. Efektivitas pembiayaan merupakan faktor penting yang senantiasa diperhitungkan bersamaan dengan efisiensi. Artinya, suatu program kegiatan tidak hanya menghitung waktu yang singkat, tetapi tidak memperhatikan anggaran yang harus dikeluarkan seperti biaya operasional dan dana pemeliharaan sarana yang mengarah pada pemborosan. Kepala Madrasah bersama-sama guru dan Komite Madrasah dalam menentukan anggaran pembelajaran harus berdasarkan kebutuhan yang riil dan benar-benar sangat dibutuhkan untuk keperluan dalam rangka menunjang penye- 
lenggaraan proses pembelajaran yang bermutu. (Ardiansyah, www.kabar-pendidikan. blogspot. com, www.kmp-malang.com; dan www. Arminaperda na.blogspot.com,http://grosirlaptop. blogspot.com

Lebih lanjut, analisis biaya dalam pendidikan mencakup keefektifan biaya (cost affectiveness), keuntungan biaya (cost benefit), kemanfaatan biaya (cost-utility), dan kefisibilitasan biaya (cost- feasibility). Selanjutnya, secara rinci masing- masing analisis biaya diuraikan sebagai berikut: 1) Analisis keefektifan biaya. Suatu pekerjaan disebut efektif kalau pekerjaan itu dikerjakan dengan tepat dan mencapai tujuan yang diinginkan. Biaya pendidikan digunakan secara efektif berarti biaya itu diarahkan hanya untuk mencapai tujuan pendidikan yang ternyata sesudah selesai pekerjaan mendidik itu tujuan yang direncanakan semula benar-benar tercapai; 2) Analisis keuntungan biaya. Analisis ini menghubungkan antara besar biaya yang dikeluarkan dengan besar pendapatan setelah menjalani pendidikan atau latihan; 3) Analisis kemanfaatan biaya adalah analisis yang berusaha membandingkan biaya yang digunakan oleh suatu alternatif dengan estimasi manfaatnya atau nilai outcomenya; dan 4) Analisis kefisibilitas biaya. Analisis ini tidak dapat diukur secara kuantitatif seperti analisis sebelumnya, analisis ini hanya melihat apakah biaya yang dipakai oleh alternatif itu cukup atau tidak, bila dihubungkan dengan dana yang tersedia. Bila biaya alternatif melebihi dana dan sumber-sumber pendidikan lainnya, maka rencana itu tidak dapat dilaksanakan, atau alternatif tersebut tidak fisibel.

Analisis mengenai biaya produksi pendidikan pada dasarnya menggunakan model teori "input- prosesoutput" di mana Madrasah dipandang sebagai suatu sistem industri jasa. Menurut Blaug (1992) dan (Idochi dan Anwar, 2004), kita menghadapi suatu kelemahan yang merembes pada fungsi produksi pendidikan, bahwa hubungan antara input Madrasah di satu pihak, dan output Madrasah di lain pihak secara konvensional diukur melalui skors-skors achievement." (Sopiali, 2018)

Perencanaan pendidikan harus menggunakan sebaik mungkin sumber daya yang tersedia, mengawasi sumber daya yang ada terhadap permintaan atas sumber daya tersebut, dan men-support setiap argumen dengan analisa kuantitatif dengan menggunakan bantuan cost analysis ini. Ada beberapa cara dalam mengidentiikasikan dan mengukur biaya pendidikan yang terkait dengan hubungan antara input dan output alam pendidikan

Biaya Uang vs Biaya Oportunitas Input dari pendidikan dapat diukur dalam bentuk uang, dan dapat juga diukur dari seluruh dari sumber daya rill yang digunakan dalam proses pendidikan (waktu guru/ dosen, waktu murid, waktu staf, buku, material, peralatan, gedung). Meskipun tidak dapat diukur secara langsung dengan uang, tetapi sumber daya ini memiliki nilai karena dapat digunakan dibidang lainnya, sehingga dinamakan "opportunity costs". Konsep opportunity costs lebih luas daripada konsep money costs/expenditure, karena tidak hanya mencakup uang saja, tapi pada sumber daya rill yang direpresentasikan dengan pengeluaran uang walaupun tidak dibeli/dijual. Contoh seperti: Nilai waktu guru/dosen yang dapat disamakan dengan sejumlah gaji, Waktu siswa masuk Madrasah yang dapat disamakan apabila dia menadapatkan pekerjaan, Sukarelawan yang tidak dibayar tapi memiliki alternatif penggunaan yang lain, sehingga memiliki economic value dan opportunity costs, Nilai tanah atau bahan mentah hasil hibah Opportunity costs dari pendidikan dapat diukur sebagai biaya kepada individu (private costs) seperti biaya pendidikan, buku, dan peralatan dan biaya kepada masyarakat (social cost) seperti biaya gaji guru dan staf, buku, peralatan, bahan mentah, gedung Kebanyakan analisis biaya pendidikan dikonsentrasikan kepada pengeluaran uang daripada opportunity costs, padahal keduanya sama pentingnya. Beberapa analysis biaya, seperti costs beneit analysis, menggunakan biaya opportunitas daripada biaya uang

Biaya Modal vs Biaya Operasional/Rutin Biaya operasional meliputi semua pengeluaran pada barangbarang konsumtif seperti buku, stationery, bahan bakar, dan jasa lainnya yang dapat membawa beneit dalam jangka menengah atau pendek. Capital costs atau expenditure meliputi pembelian durable assets seperti gedung atau perlengkapan yang diharapkan memberikan keuntungan untuk jangka panjang. Pembelian barang-barang capital/modal ini dapat dikatakan sebagai suatu investasi. Baik current maupun capital expenditure dapat diukur secara actual atau current prices atau dalam tingkat harga yang konstan/constant 
purchasing power. Analysis biaya ini sebagai "elemental costs analysis sukses diaplikasikan pada pendidikan yang menghasilkan pengurangan biaya, karena membanding bangunan- bangunan yang menggunakan material yang berbeda, teknik pembangunan berbeda untuk meningkatkan eifsiensi dan mengurangi biaya pembanguan gedung baru.

Jenis Pembiayaan Pendidikan langsung dari pemerintah dengan menghitung jumlah peserta didik yang ada yakni berjumlah Rp. 3.810.490.000 di MadrasahAliyah Negeri 3 Kota Payakumbuh pada tahun 2021dengan pengalokasian dana sebagai berikut :

\section{Table 3}

Jenis Pembiayaan Pendidikan Langsung dari Pemerintah

\begin{tabular}{cll}
\hline NO & \multicolumn{1}{c}{ PROGRAM/AKTIVITAS } & \multicolumn{1}{c}{ JUMLAH BIAYA } \\
\hline 1 & Belanja Keperluan perkantoran & 34.320 .000 \\
\hline 2 & Belanja Barang Operasional Lainnya & 68.800 .00 \\
\hline 3 & Belanja Bahan & 22.381 .00 \\
\hline 4 & Belanja Honor Out Put Kegiatan & 9.540 .000 \\
\hline 5 & Belanja Barang Persediaan Barang Komsumsi & 18.659 .000 \\
\hline 6 & Belanja Langganan Listrik & 3.500 .000 \\
\hline 7 & Belanja Langganan Telpon & 3.500 .000 \\
\hline 8 & Belanja Pemeliharaan Gedung dan Bangunan & 18.000 .000 \\
\hline 9 & Belanja pemeliharaan Perlatan dan mesin & 3.000 .000 \\
\hline 10 & Belanja barang operasional lainnya & 1.000 .000 \\
\hline 11 & Belanja Bahan Ujian & 13.000 .000 \\
\hline 12 & Belanja Bahan Ekstrakurikuler & 22.000 .000 \\
\hline 13 & Belanja Barang Non Operasional- Penangan Pandemi Covid 19 & 6.000 .000 \\
\hline 14 & Belanja Modal Peralatan dan mesin (komputer, CCTV, Kamera & 43.000 .000 \\
& dan scanner) & 10.000 .000 \\
\hline 15 & Belanja modal lainny (pengadaan buku) & 3.349 .055 .000 \\
\hline 16 & Gaji Tunjangan PNS & 3.810 .490 .000 \\
\hline
\end{tabular}

Jenis Pembiayaan Pendidikan tidak langsung, biaya pribadi, biaya masyarakat dan lain-lain Rp. 18.000.000 di MadrasahAliyah Negeri 3 Kota Payakumbuh pada tahun 2021 dengan pengalokasian dana pada umumnya untuk guru honor, pembangunan swadaya gedung serta kebutuhan operasional rapat atau sosial lainnya.

Melalui tabel diatas dapat dilakukan analisisnya bahwa pembiayaan pendidikan MadrasahAliyah Negeri 3 Kota Payakumbuh sudah dapat melakukan kegiatan belajar-mengajar secara optimal karena tidak ada masalah keuangan baik untuk menggaji guru maupun untuk pengadaan sarana dan prasarana pembelajaran. MadrasahAliyah Negeri 3 Kota payakumbuh sudah mampu mengelola keuangan yang ada sehingga dapat menghindari penggunaan biaya yang tidak perlu/ tidak direncanakan dalam Rencana Anggaran Pendapatan dan Belanja Madrasah(RAPBM). Efektivitas pembiayaan merupakan salah satu alat ukur efisiensi, sehingga program kegiatan tidak hanya dihitung berdasarkan biaya tetapi juga waktu, dan lebih penting lagi menghindari dan menseleksi penggunaan dana operasional, pemeliharaan, dan biaya lain yang mengarah pada pemborosan

\section{KESIMPULAN}

Atas dasar hasil kajian secara teori dapat disimpulan faktor-faktor yang mempengaruhi lambatnya perkembangan MadrasahAliyah Negeri 3 Kota Payakumbuh adalah biaya pendidikan. Yang mana biaya pendidikan di MadrasahAliyah Negeri 3 Kota Payakumbuh dipengaruhi oleh: a) kenaikan harga (rising prices); b) perubahan relatif dalam gaji guru (teacher's sallaries); c) perubahan dalam populasi dan kenaikannya persentase peserta didik, d) meningkatnya standar pendidikan (educational standards); e) 
meningkatnya jumlah anak yang meninggalkan Madrasah; dan f) meningkatnya tuntutan terhadap pendidikan lebih tinggi (higher education). Faktor yang paling mendominasi adalah perubahan dalam populasi dan kenaikannya persentase peserta didik. Semakin banyak peserta didik semakin besar biaya yang masuk. Jenis biaya yang masih sering dikeluhkan oleh sebagian besar masyarakat Indonesia berkaitan dengan biaya yang harus dikeluarkan oleh orang tua peserta didik (biaya pribadi). Pembiayaan pendidikan di MadrasahAliyah Negeri 3 Kota Payakumbuh belum efektif dan belum efisien, perlu dikembangkan model pendekatan human capital.

\section{DAFTAR PUSTAKA}

Ardiansyah, www.kabar-pendidikan.blogspot.com, www.kmp-malang.com; dan www.Arminaperda na.blogspot.com, http://grosirlaptop. blogspot.com diambil 10 Juni 2021

Asiah, N. (2016). Inovasi Pembelajaran Pendidikan Agama Islam melalui E-Learning di SMA Budaya Bandar Lampung. 6(1), 77-101.

Fattah, N. (2008). Pembiayaan Pendidikan: Landasan Teori dan Studi Empiris. Jurnal Pendidikan Dasar, 2(April), 417-436.

Feiby Ismail. (n.d.). Manajemen Berbasis Sekolah: Solusi Peningkatan Kcalitas Pendidikan.

Ferdi, W. P. (2013). Pembiayaan Pendidikan : Suatu Kajian Teoritis Financing of Education: A Theoritical Study. 565-578.

Helmina, B. (2013). Penentuan Harga Pokok Produksi Berdasarkan Metode Full Costing Pada Pembuatan Etalase Kaca Dan Alumunium Di Ud. Istana Alumunium Manado. Jurnal EMBA 217 Vol.1 No.3 September 2013, Hal. 217-224, 1(3), 217-224.

Kemendikbud, 2020. (2020). Surat Edaran Nomor 4 Tahun 2020 tentang Pelaksanaan Kebijakan Pendidikan dalam Masa Darurat Penyebaran Coronavirus disease (Covid-19) (p. 300).

Musthafa, L. A.-H. (2017). Model Pembiayaan Pendidikan MadrasahAliyah Swasta. Journal of Islamic Education, 2(2), 228.

Peraturan Pemerntah. (2008). No Peraturan Pemerintah Republik Indonesia Nomor 48 Tahun 2008 (pp. 157).

Presiden Republik Indonesia. (2008). Peraturan Pemerintah Republik Indonesia Nomor 19 Tahun 2017 tentang Perubahan atas Peraturan Pemerintah Republik Indonesia Nomor 74 Tahun 2008 tentang Guru. http://sipuu.setkab.go.id/PUUdoc/175233/PP 19 Tahun 2017.pdf

Sopiali, A. (2018). Dalam Pendidikan Islam ( Planning , Organizasition, Implementation, dan Supervision ) Ade Sopiali Program Pascasarjana, Program Studi manajemen Pendidikan Islam PENDAHULUAN Banyak hal yang menjadi penyebab tidak dapat berkembang dengan baik sarana dan .06(2), 103-118.

Sunarsi, Y. K. D. (2013). Pengaruh Strategis Penetapan Harga terhadap peningkatan Jumlah Siswa Pada SMK PGRI Balaraja. Journal of Chemical Information and Modeling, 53(9), 1689-1699.

Supardi. (2015). Arah Pendidikan di Indonesia dalam Tataran Kebijakan dan Implementasi. Formatif: Jurnal Ilmiah Pendidikan MIPA, 2(2), 111-121. https://doi.org/10.30998/formatif.v2i2.92

UU 20 tahun. (2003). Undang-Undang Republik Indonesia Nomor 20 Tahun 2003 tentang sistem pendidikan Nasional.

Zulfa, U. (n.d.). Membangun MadrasahBermutu Melalui Praktik Manajemen Pembiayaan Pendidikan Berbasis Potensi Umat (Sebuah Alternatif Model Pembiayaan Pendidikan di Indonesia). 1(1), 12-23. 